\title{
Anatomical Structure of Aboveground and Underground Organs of the Rare Endemic Species Iris (Juno) magnifica vved., Growing under Natural Conditions of the Zeravshan Ridge, Samarkand Mountains
}

\author{
Nargiza K. Rakhimova*, Guljan M. Duschanova, Akida T. Abdullaeva, Eldor E. Temirov \\ Laboratory Anatomy and Cytoembryology of the Tashkent Botanical Garden Named after Academician F.N. Rusanov, Institute \\ of Botany of the Academy of Sciences, Tashkent, Uzbekistan \\ Email: *nargizarah1980@mail.ru, guljon.duschanova@mail.ru
}

How to cite this paper: Rakhimova, N.K., Duschanova, G.M., Abdullaeva, A.T. and Temirov, E.E. (2020) Anatomical Structure of Aboveground and Underground Organs of the Rare Endemic Species Iris (Juno) magnifica vved., Growing under Natural Conditions of the Zeravshan Ridge, Samarkand Mountains. American Journal of Plant Sciences, 11, 1453-1466.

https://doi.org/10.4236/ajps.2020.119105

Received: August 11, 2020

Accepted: September 24, 2020

Published: September 27, 2020

Copyright $\odot 2020$ by author(s) and Scientific Research Publishing Inc. This work is licensed under the Creative Commons Attribution International License (CC BY 4.0).

http://creativecommons.org/licenses/by/4.0/

\begin{abstract}
The morpho-anatomical structure of the aboveground and underground organs of the rare endemic species Iris (Juno) magnifica, growing under natural conditions of the Zeravshan ridge, Samarkand mountains, has been studied for the first time. A comparative analysis of the morpho-anatomical structure of the aboveground and underground organs revealed characteristic diagnostic signs of a microscopic structure. The complex of anatomical features of the aboveground and underground organs of the studied species are species-specific and can be used to solve taxonomic problems of this genus of plants, as well as the Red Book endemic species of juno irises, are of particular interest in connection with the potential for their vegetative reproduction.
\end{abstract}

\section{Keywords}

Anatomy, Aboveground and Underground Organs, Iris (Juno) magnifica, Zeravshan Ridge, Samarkand Mountains

\section{Introduction}

In modern taxonomy, both the understanding of the volume of the genus Iris, which provides for the inclusion of the genus of bulbous and tuberous species in the system, is widespread, and Iris determines only rhizome species in its composition. 
Spanish and American scientists M. Crespo, M. Martínez-Azorín, E. Mavrodiev [1]: species of Juno Tratt. is a special group of bulbous irises, widespread in central and southwestern Asia and the Caucasus, with some representatives in the Mediterranean basin. The authors consider this group of plants with morphological, biogeographic and molecular features as an independent genus.

Central Asia is one of the centers of the variety of species of Junonian irises. According to the latest data F. O. Khasanov and N. K. Rakhimova, [2] in the flora of Central Asia, Juno irises is represented by no less than 30 species. K. Sh. Tojibaev and F. I. Karimov [3] described new species, Iris austrotschatkalica Tojibaev, F. Karim. et Turgunov from the Chatkal ridge of the Fergana Valley and Iris khassanovii Tojibaev \& Turgunov from the Gissar ridge. F. O. Khasanov et al. [4] described two species, Iris rudolphii F.O. Khass., Esankulov et Achilova and Iris victoris F.O. Khass. U. Khuz. \& N. Rakhimova, from the territory of Uzbekistan (Kelif-Sherabad ridge).

G. A. Lazkov and A. Naumenko [5] described a new species, Iris rodionenkoi Lazkov and Naumenko from Kyrgyzstan. To date, representatives of Junonian irises in Central Asia have no less than 36 species.

It is known that the anatomical signs of the leaf can be of great importance for the taxonomy of the genus Iris and the family Iridaceae [6] [7] [8] [9]. But the existence of phenotypic plasticity of anatomical features is also known, which depends on various factors, especially on the ecological conditions of the environment [11] [12] [13].

In the botanical literature in recent years, special attention has been paid to the structure of the epidermis and cuticle of the leaf. The shape of the cells of the leaf epidermis, the location, as well as the shape, location of the stomata are fairly constant generic and sometimes specific characters. Several environmental factors can affect the structure of the epidermis, without any connection with the genotype. For example, many authors believed that the size and frequency of stomata depend on environmental conditions [10] [11] [12] [13] [14].

T. Bacic [15] showed that the number and size of stomata varied depending on the influence of light and plant age. T. Nikolic [16] reports the phenotypic plasticity of the epidermal cell width caused by different lighting conditions. According to J. Pazourek [17], the stomatal frequency decreases with decreasing light intensity. G. N. Knecht and J. W. O'Leary [18] observed the development of more stomata with increased light intensity, T. W. Lucansky and K. D. Clough [19] pointed out the dependence of the anatomical features of the leaf on xeromorphism and mesomorphism of the habitat.

The Chinese and English scientists Qi-Gen Wu and D. F. Cutler [7] described the taxonomic, evolutionary and ecological significance of the leaf anatomy of 113 rhizome species and 20 intraspecific taxa from the first three subgenus Iris. The taxonomic and ecological significance of structural characters was assessed and the relationship and evolutionary position of these taxa were studied. Some species with an uncertain taxonomic position are discussed and their classifica- 
tion based on anatomical data is proposed. A correlation has been shown between some anatomical features and the type of habitat for certain types of irises. Some xeromorphic and gelomorphic characteristics of the leaf are also given.

Croatian scientists B. Mitic and Z. Pavletic [20] studied the leaf anatomy of the stenoendemic species I. croatica I. et M. Horvat. Two separate populations were analyzed and the stability of the anatomical features of the leaves was established. The revealed anatomical features of the leaf of I. croatica showed significant differences in comparison with the related species I. germanica L.

B. Mitic et al., [21] analyzed the relationships in the alpine-dinar and cultivated populations of the genus Iris, the Pallidae series. Some morphological (stem length, length of the largest leaf, greatest width of the largest leaf, length of the smallest leaf, greatest width of the smallest leaf, number of leaves and number of flowers) and anatomical features of the leaf (length and width of stomata, length and width of epidermal cells, number of stomatal and epidermal cells per $\mathrm{mm} 2$ and length of styloids). The results of cluster and PCA analysis showed that, based on the study of the anatomical features of the leaf of the Pallidae series, five main groups of populations were identified.

Researchers N. Kandemir et al. [22] studied the taxonomic significance of the anatomical features of the leaf of 10 species of Iris, subgenus Scorpiris Spach, growing in Turkey. The anatomical features of the leaf of 10 taxa were studied in detail and divided into three groups. It was found that some anatomical features of the leaf have a taxonomic marker for the differentiation of taxa: micropapillae and papillae in the upper and lower epidermis of the leaf, mesophyll structure, length-width of the upper epidermis, diameter of the lower epidermis, cuticle thickness, length-width of palisade and spongy parenchyma, diameter trachea, length-width and submergence of stomata, number of layers of mesophyll cells, number of layers of palisade and spongy parenchyma, type and density of crystals, presence and absence of styloids, number and shape of sclerenchyma cap, these characters can be significantly distinguishing taxonomic characters among taxa of three groups.

In the leaves of taxa, similar anatomical features are the following: the presence of the same types of stomata, the presence of sclerenchyma in vascular bundles and at the corners of leaves and parenchymal cells in vascular bundles; crystalline granules were also found. I. persica differs from the other taxa tested, but two species (I. peshmeniana and I. aucheri) showed closely related relationships.

We have previously studied the morpho-anatomical structure of the vegetative organs of some Iris species (I. sogdiana, I. korolkowii, I. stolonifera, I. alberti) and Juno (J. svetlanae, J. hippolytii, J. narbuti), in order to identify diagnostic and adaptive features [23] [24] [25] [26] [27].

Anatomists and taxonomists of different countries are studying the anatomical structure of the aboveground and underground organs of Juno species to identify adaptive and diagnostic characters, which is of particular importance in 
the preservation of rare, endemic and endangered plants.

Data on the anatomical structure of the aboveground and underground organs of the rare endemic species Iris (Juno) magnifica, growing in natural conditions in Uzbekistan, have not been studied. This determines the relevance and novelty of our research.

The aim of the study is to study the anatomical structure of the aboveground and underground organs of the rare endemic species Iris (Juno) magnifica, in order to identify adaptive, diagnostic and taxonomic characters.

\section{Materials and Methods}

Iris (Juno) magnifica, listed in the Red Book of Uzbekistan, is a rare endemic of the Zeravshan Range with status 2 [28]. The perennial corm plant. The roots are strongly thickened, fusiform. The bulb $3 \mathrm{~cm}$ thick. Stem $25-70 \mathrm{~cm}$ tall, with spread leaves; internodes are clearly visible. Leaves are light green, shiny, sickle-shaped, almost bordered along the edge, rough; lower $3-5 \mathrm{~cm}$ wide. In cracks in rocks and on fine-earth areas among rocks in the lower belt of mountains. Samarkand region (Samarkand mountains). Ecology: In the middle belt of mountains. Habitat: Endem of the Zeravshan Ridge (Samarkand mountains).

The material was collected from the Zeravshan ridge, Takhta-Karacha pass, at an altitude of $4110 \mathrm{~m}$ above sea level. m. 39035'038" s. $67001^{\prime} 7396$ " east longitude 04/16/2018. Taxonomic descriptions were made in accordance with the system of B. Mathew [29]. Morphological descriptions, ecology and area are given from "Flora of the USSR" and "Flora of Uzbekistan" by A.I. Vvedensky [30], the names of taxa are given from the database according to the site http://www.theplantlist.org:

Samples of fresh plants were fixed in $70 \%$ alcohol solution. For the preparation of sections of vegetative organs, a manual method was used. The epidermis was studied on paradermal and cross sections. Paradermal sections of the leaf epidermis were prepared manually using forceps. The transverse sections of the leaf, sheath and stem were prepared by hand using a safety razor.

Cross-sections of the leaf and bulb are made through the middle, and the sheath of the leaf, stem and fleshy root through the base. Sections were stained with methylene blue, followed by gluing in glycerin-gelatin [31]. Descriptions of the main tissues and cells are given according to K. Esau [32], the epidermis according to N.A. Aneli [33]. Anatomical measurements were taken with a micrometer eyepiece attached to the microscope. The number of stomatal and epidermal cells was counted per $1 \mathrm{~mm}^{2}$ of surface area. Various anatomical features of vegetative organs (leaf, leaf's vagina and stem): adaxial and abaxial sides of the leaf epidermis; mesophyll structure; the height of the epidermal cells; cuticle thickness; parenchyma cell diameter; diameter and number of vessels; length/width of stomata; submerged stomata; the number of layers of mesophyll cells; diameter and number of cell layers in the spongy, aquiferous and crustal parenchyma; height, width and number of layers of the palisade parenchyma; the diameter and number of layers of collenchymal and sclerenchymal cells were 
measured with a micrometer under a microscope.

The measurements were carried out depending on the organ, tissues and cells in 30 -fold repetition with an eyepiece with a micrometer, followed by conversion to microns. Micrographs of anatomical signs of vegetative organs were made with a computer microphoto attachment with a digital camera brand A123 from Canon under a Motic B1-220A-3 microscope. Statistical processing of quantitative data was carried out in 30 -fold repetition for each anatomical feature; the mean and the standard deviations of these measurements were calculated using a personal computer ( $M S$-Excel program) according to generally accepted criteria [34].

\section{Results and Discussion}

\subsection{Iris (Juno) Magnifica Vved}

Leaves are light green, shiny, sickle-shaped, almost bordered along the edge, rough; bottom 3 - $5 \mathrm{~cm}$ wide.

\subsection{The Structure of the Leaf}

In the paradermal section, the basic cells of the epidermis, by the nature of the boundary walls, can be attributed to the rectilinear clan (Aneli, 1975). Epidermal cells belong to the rectangular type, in which rectangular cells are located along the vertical axis of the leaf.

Epidermal cells are most numerous on the abaxial side (there are $60.8 \pm 0.72$ of them per $1 \mathrm{~mm}^{2}$ ), few on the adaxial side $41.8 \pm 0.33$. Leaves are hypostomatic. The form of the combination of stomatal cells (from the surface) is oval (36.4 $\pm 0.39 \mu \mathrm{m}$ in length, $29.5 \pm 0.09 \mu \mathrm{m}$ in width), stomata are of the lenticular-equally thickened type [33], in which two identical semilunar cell shapes arranged symmetrically. On the frontal plane, the thickened shells are almost uniform. The slit is round. The stomata are anomocytic type, weakly submerged 9.3 $\pm 0.08 \mu \mathrm{m}$, there are $111.6 \pm 2.17$ of them per $\mathrm{mm}^{2}$ (Figure 1 ).

The leaf mesophyll on the cross section is of the isoform type, represented by spongy cells on both sides of the leaf and vascular-fibrous vascular bundles. The adaxial epidermis consists of one row of elongated cells with thick outer walls (7.4 \pm 0.08 microns), the abaxial epidermis consists of rounded oval cells. Adaxial epidermal cells are large compared to abaxial ones $(90.9 \pm 1.37-37.0 \pm 0.32$ $\mu \mathrm{m}$ in height). The spongy parenchyma consists of $7-8$ rows of large $(31.5 \pm$ $0.42 \mu \mathrm{m}$ ) small, chlorophyll-bearing rounded cells.

The main and lateral veins protrude on the abaxial side of the leaf, the vascular-fibrous vascular bundles are located in the central part of the leaf mesophyll. Under the abaxial epidermis and above the vascular-fibrous vascular bundles, there is an angular, large $(7.5 \pm 0.09 \mu \mathrm{m}) 11$ - 14 row collenchyma. The main vein has 1 conductive bundle. Conducting bundles are closed, collateral, numerous, consisting of phloem and xylem, with $7-8$ small vessels (13.6 \pm 0.09 $\mu \mathrm{m})$ (Figure 1). 


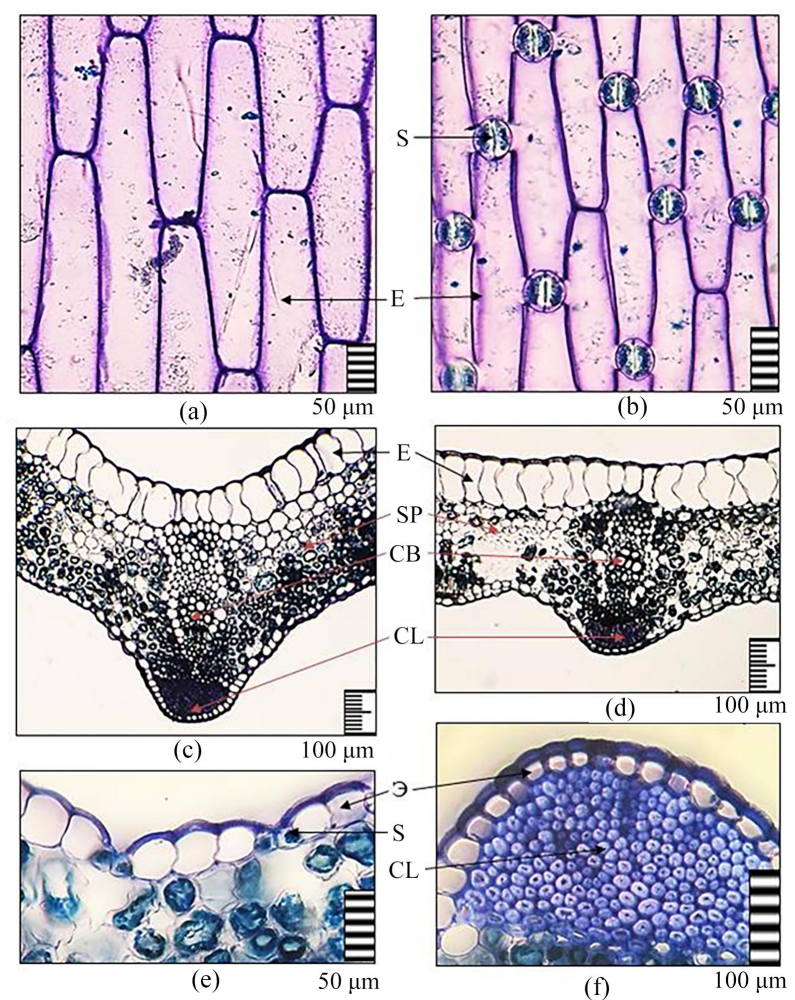

Figure 1. Anatomical structure of the epidermis and mesophyll of the leaf of Iris (Juno) magnifica: (a) adaxial epidermis; (b) abaxial epidermis; (c) detail of the main vein of the leaf mesophyll; (d) detail of the lateral vein of the leaf mesophyll; (e) submerged stomata; (f) corner collenchyma under the conducting beams. Legend: $\mathrm{CB}$-conducting bundle, $\mathrm{CL}-$ collenchyma, E-epidermis, S-stomata. magnification -50 - 100 micron.

\subsection{The Structure of the Leaf's Vagina}

Sheaths of the sheet in a transverse section of the parenchymal-bundle type. The upper and lower epidermis consist of one row of rounded-oval cells $71.4 \pm 0.62$ $35.7 \pm 0.34 \mu \mathrm{m}$ in height, with thick outer walls $14.3 \pm 0.08 \mu \mathrm{m}$. The cells of the abaxial epidermis are larger than those of the adaxial epidermis. The stomata are submerged - $14.7 \pm 0.07$ microns. The parenchyma of the leaf's vagina consists of $10-11$ rows of large and small cells with a diameter of $64.8 \pm 0.71 \mu \mathrm{m}$, rounded-oval. Vascular-fibrous vascular bundles are located in the center of the leaf's vagina and consist of phloem and xylem with 8-11 large vessels with a diameter of $28.6 \pm 0.27 \mu \mathrm{m}$ (Figure 2).

\subsection{The Structure of the Stem}

The base of the stem on the cross section is rounded, the structure of the parenchymal-bundle type. The epidermis consists of one row of rounded-oval-shaped cells $33.8 \pm 0.35 \mu \mathrm{m}$ in height, with a thin outer wall $6.3 \pm 0.04 \mu \mathrm{m}$.

The primary cortex consists of $10-12$ rows of rounded-oval cells, with a diameter of $51.5 \pm 0.53 \mu \mathrm{m}$, located between the epidermis and the central cylinder. The primary cortex is separated from the central cylinder by a ring of sclerenchyma. 
The central cylinder is extensive, rounded-oval, and consists of thin-walled parenchymal cells. Among the thin-walled parenchymal cells of the central cylinder, there are numerous conductive bundles, randomly scattered over the underlying tissue; hydrocytic cells are also found. Sclerenchyma is annular, thin-walled, consists of 4 - 5 rows of cells with a diameter of $31.3 \pm 0.27 \mu \mathrm{m}$. On the periphery of the stem, under the sclerenchymal cells, there are conductive bundles of a closed collateral type. The vascular bundles consist of phloem and xylem, with $10-12$ large and small vessels with a diameter of $22.5 \pm 0.02 \mu \mathrm{m}$ (Figure 3 ).

On the basis of revealing the ratio of quantitative indicators of the aboveground organs of Iris (Juno) magnifica, the following predominant xeromorphic and mesomorphic signs were determined, manifested in various combinations: a thickened outer wall of the epidermis; small, numerous epidermal, spongy and parenchymal cells; numerous, submerged stomata; small, multi-row sclerenchymal and collenchymal cells; small and numerous vessels in vascular bundles are xeromorphic signs.

Thin-walled, large, few epidermal, spongy and parenchymal cells; few, not submerged stomata; large, few-row sclerenchymal and collenchymal cells; large and few vessels in the conducting bundles are mesomorphic signs. The results obtained on the anatomical structure of the aboveground organs of Iris (Juno) magnifica showed that mesomorphic and xeromorphic signs predominate, which shows the rarity of this species (Figure 3 ).

\subsection{The Structure of the Adventitious or Fleshy Roots}

In monocotyledonous plants, in addition to the embryonic root of the embryo, during germination, adventitious roots immediately develop from the base of the stem (Figure 4).

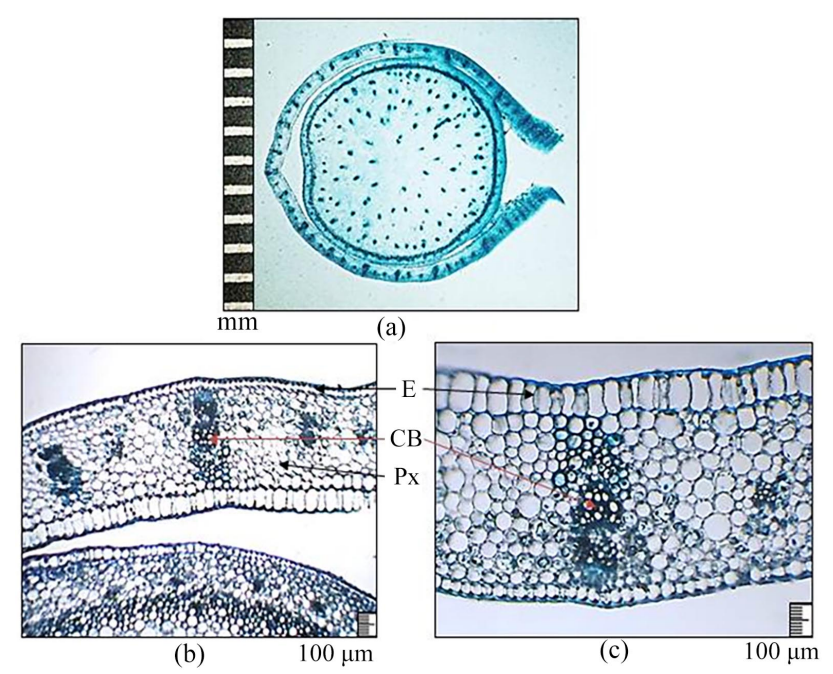

Figure 2. Anatomical structure of the leaf's vagina of Iris (Juno) magnifica: (a) scheme of the leaf's vagina; (b)-(c) detail of the leaf's vagina. Legend: $\mathrm{CB}$-conducting bundle, E-epidermis, $\mathrm{Px}$ - parenchyma. magnification -50 100 micron. 


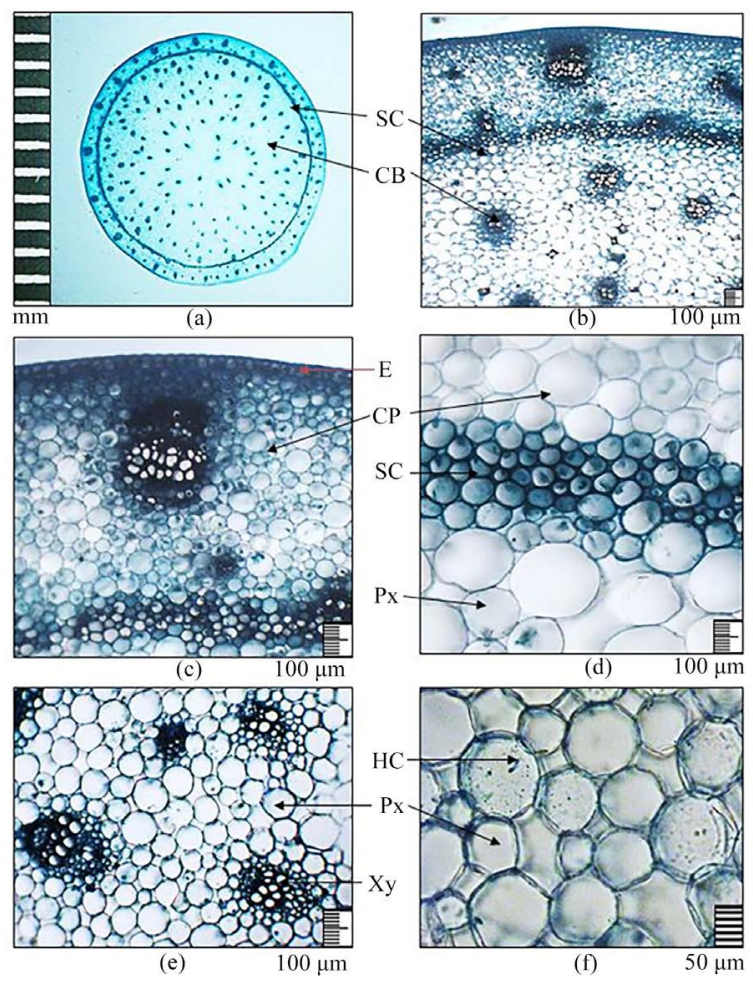

Figure 3. Anatomical structure of the stem of Iris (Juno) magnifica: (a) scheme; (b) detail; (c) cortex parenchyma; (d) sclerenchyma ring; (e) conducting beams; (f) core. Legend: E-epidermis, HD-hydrocytic cells, SC-sclerenchyma, $\mathrm{CP}$-cortex parenchyma, $\mathrm{Xy}$-xylem, $\mathrm{CB}$-conducting bundle, $\mathrm{Px}$-parenchyma. magnification -50 - 100 micron.

On a transverse section, the adventitious or fleshy roots of Iris (Juno) magnifica is rounded with a diameter of $10-11 \mathrm{~mm}$, of a bundle-type structure and is divided into three parts: rhizoderm, primary crustal parenchyma and central cylinder. Rhizoderm consists of one row of tightly closed cells. The primary cortex consists of thin-walled, rounded-oval cells and is represented by three distinct layers: exoderm, mesoderm, and endoderm. The exoderm was located under the rhizoderm. Exoderm cells are polygonal, tightly closed, and consists of 4 - 5 rows. Under the exoderm was the mesoderm (Figure 4, Figure 5).

The mesoderm consists of primary cortical parenchymal cells and is located outside of the endoderm. Consists of loosely located rounded-oval cells with a large diameter of $135.71 \pm 1.41 \mu \mathrm{m}$, there are intercellular spaces, through which there is an intensive gas exchange. The cells of the cow parenchyma are large and they accumulate more nutrients

The endoderm was located under the mesoderm. The endoderm consists of a single row of oval-shaped cells. Endoderm cells control the flow of water and dissolved minerals from the cortex to the central cylinder and vice versa. The central cylinder occupies the central part of the root. The outer layer of the pericycle of the central cylinder is adjacent to the endoderm. The pericycle consists of one row of oval-shaped cells. In the central part of the cylinder there are vascular bundles consisting of phloem and xylem (Figure 5). 

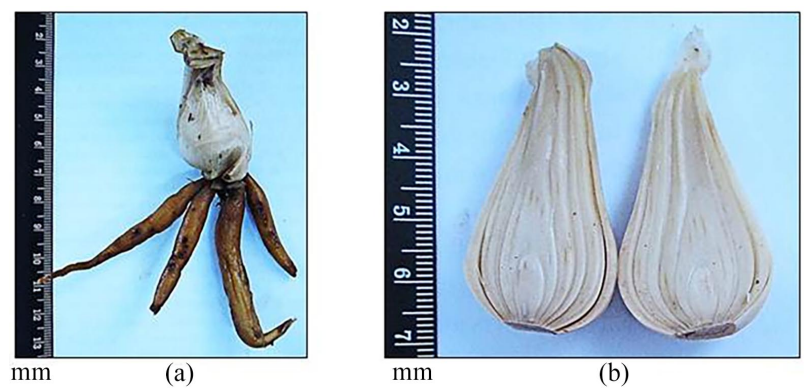

Figure 4. General view of the bulb of Iris (Juno) magnifica: (a) general view of the bulb and adventitious root; (b) longitudinal section of the bulb.
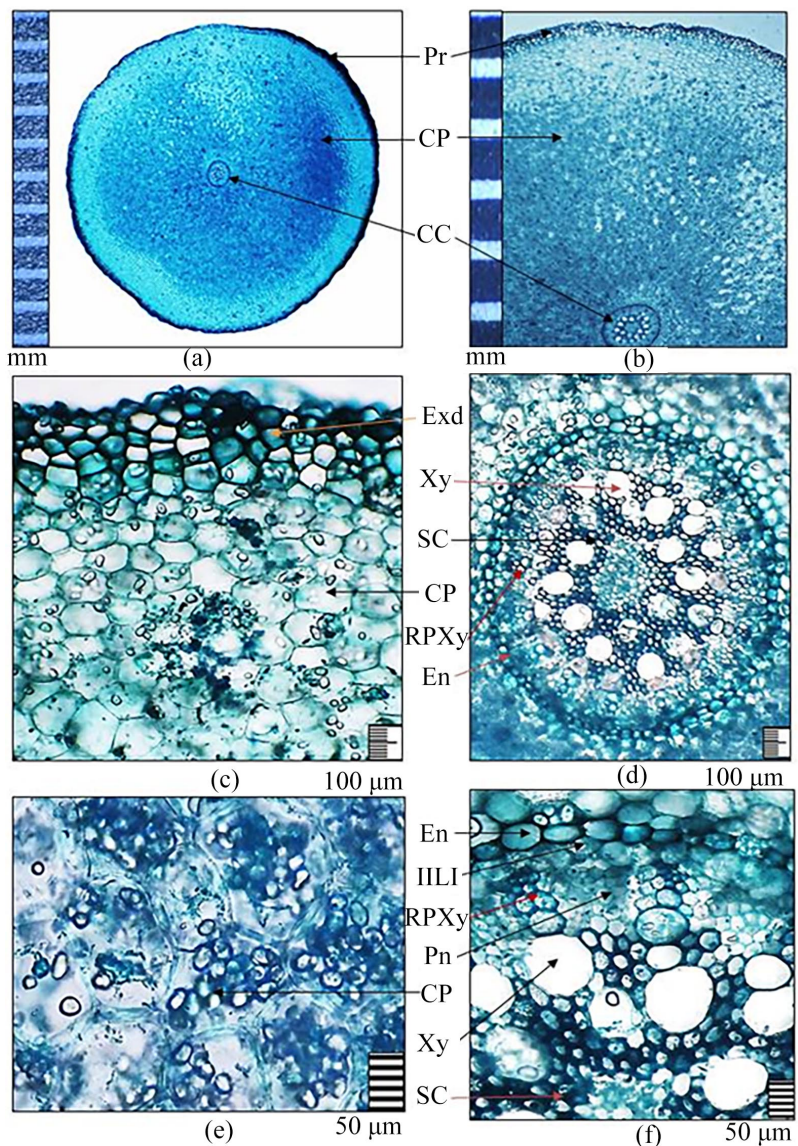

Figure 5. Anatomical structure of the adventitious or fleshy root of Iris (Juno) magnifica: (a) general view of the adventitious or fleshy root; (b) detail; (c) exoderm and cortex parenchyma, (d)-(f) conducting bundles; (e) cortex parenchyma. Legend: $\mathrm{CP}-$ crustal parenchyma, $\mathrm{Xy}-\mathrm{xylem}, \mathrm{RPXy}-$ ray primary xylem, $\mathrm{Pr}$ - periderm, PC-pericycle, SC-sclerenchyma, $\mathrm{Ph}$ - phloem, CC-central cylinder, Exd-exoderm, En-endoderm. magnification -50 - 100 micron.

Conducting bundles are closed concentric centroxylem type. The roots are characterized by alternation of the primary xylem and primary phloem areas in the central parts of the cylinder. Xylem forms a star, and phloem is located between its rays. The rays consist of 15 - 16 rays of the primary xylem. In the very center of the cylinder there are $14-15$ small xylems with a diameter of $92.86 \pm$ 
0.93 microns, thick-walled sclerenchymal and parenchymal cells. Conductive bundles are sclerified due to sclerenchymal cells with a diameter of $21.43 \pm 0.19$ (Figure 5).

When studying the anatomical structure, the following diagnostic signs were established for the adventitious or fleshy root: the root has a bundle type of structure and is divided into three parts: rhizoderm, primary crustal parenchyma and central cylinder. Rhizoderm is the primary integumentary tissue, consisting of one row of tightly closed cells. The primary cortex consists of thick- and thin-walled, rounded-oval cells and is represented by three distinct layers: exoderm, mesoderm and endoderm. Exoderm cells are oval, tightly closed. The mesoderm consists of primary parenchymal crustal cells, in which nutrients are accumulated. The central cylinder occupies the central part of the root. The pericycle consists of one row of oval-shaped cells. In the central part of the cylinder, there are conducting bundles consisting of phloem and xylem. Conducting bundles are closed concentric centroxylem type. The roots are characterized by alternation of the primary xylem and primary phloem areas in the central part of the cylinder. Xylem forms a star, and phloem is located between its rays. In the very center of the cylinder there are 14-16 large xylems and thick-walled sclerenchymal and parenchymal cells. The conducting bundles are sclerified (Figure 6).

\subsection{The Structure of the Bulb}

The bulb is an underground shoot with a short, flattened stem and fleshy, close, scaly leaves; stores water and nutrients (carbohydrates), serves for vegetative renewal and reproduction (Figure 6).

The bulb is parenchymal-bundle type in cross section. Adaxial and abaxial epidermis consists of one row of rounded-oval cells. The height of epidermal cells is $28.6 \pm 0.33 \mu \mathrm{m}$, with a thin-walled cuticle of $4.7 \pm 0.03 \mu \mathrm{m}$. The cells of the adaxial and abaxial epidermis are large, elongated, with a thin outer cuticle wall.

The parenchyma of the bulb consists of $18-20$ rows of large and small round-oval cells with a diameter of $121.9 \pm 1.3 \mu \mathrm{m}$. Among the parenchymal cells are hydrocytic cells. Parenchymal cells accumulate nutrients (Figure 6).

Vascular-fibrous vascular bundles are located in the center of the bulb, not numerous, of a closed collateral type, consisting of phloem and xylem, with 6 - 7 large and small vessels with a diameter of $27.8 \pm 0.25 \mu \mathrm{m}$. Calcium oxalate crystals occur between parenchymal cells (Figure 6).

When studying the anatomical structure of the bulb, the following diagnostic signs were established: the bulb has a bundle type of structure; adaxial and abaxial epidermis consists of one row of rounded-oval cells. Parenchymal cells are thin-walled, large and small-celled, multi-row, and they accumulate a large number of nutrients. Vascular-fibrous vascular bundles are located in the center, closed collateral type, consisting of phloem and xylem, with 4 - 5 large and small vessels (Figure 6). 

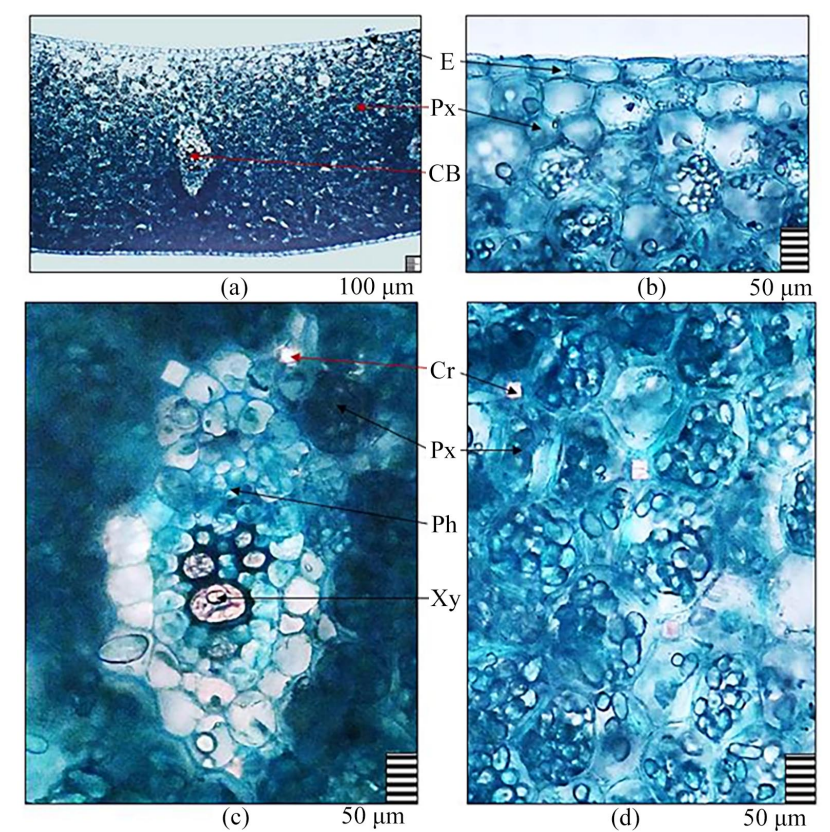

Figure 6. Anatomical structure of the bulb of Juno magnifica: (a) scheme; (b) adaxial epidermis and parenchymal cells; (c) conductive bundle, (d) parenchymal cells and nutrients. Legend: $\mathrm{CB}$-conducting beams, $\mathrm{Cr}-$ crystals calcium oxalate, E-epidermis, $\mathrm{Ph}$-phloem, $\mathrm{Px}$-parenchymal cells, $\mathrm{Xy}-\mathrm{xylem}$. magnification -50 - 100 micron.

\section{Conclusion}

Thus, a comparative morphological and anatomical structure of the aboveground and underground organs of Iris (Juno) magnifica was carried out. Diagnostic signs of microscopic structure were determined: the basic cells of the leaf epidermis by the nature of the boundary walls belong to the rectilinear clan to the rectangular-walled type. Leaves are hypostomatic. The form of the combination of stomatal cells is oval, the stomata are of the lenticular-equally thickened type. The mesophyll of the leaf on the cross section is of the isoform type of structure, represented by spongy cells on both sides of the leaf and vascular fibrous vascular bundles. Under the abaxial epidermis and above the vascular-fibrous vascular bundles, there is a corner collenchyma. In the main vein of the leaf, there is 1 closed, collateral-type conducting bundle. The sheaths of the leaf and the base of the stem on the cross section are of the parenchymal-bundle type. The primary bark of the stem is separated from the central cylinder by a ring of sclerenchyma. On the periphery of the stem, under the sclerenchymal cells, there are conductive bundles of a closed collateral type. The anatomical structure, the following diagnostic signs were established for the adventitious or fleshy root: the root has a bundle type of structure and is divided into three parts: rhizoderm, primary crustal parenchyma and central cylinder. Conducting bundles are a closed concentric centroxylem type. The roots are characterized by alternation of the primary xylem and primary phloem areas in the central part of the cylinder. Xylem forms a star, and phloem is located between its rays. The 
anatomical structure of the bulb and the following diagnostic signs were established: the bulb has a bundle type of structure. Parenchymal cells accumulate a large number of nutrients. Vascular-fibrous vascular bundles are located in the center, closed collateral type. The complex of anatomical features of the aboveground and underground organs of each of the studied species of Juno irises are species-specific and can be used to solve taxonomic problems of this genus of plants. The studied endemic species of Juno irises from the Red Data Book are of particular interest due to the potential for their vegetative reproduction.

\section{Acknowledgements}

The current research is done under the project VA-FA-F5-008 "Scientific bases for the conservation of the gene pool of rare endemic species of the flora of Uzbekistan ex situ and the biology of their reproduction".

\section{Conflicts of Interest}

The authors declare no conflicts of interest regarding the publication of this paper.

\section{References}

[1] Crespo, M.B., Martínez-Azorín, M. and Mavrodiev, E.V. (2018) Notes on Taxonomy and Nomenclature of Juno Irises (Juno, Iridaceae). Phytotaxa, 376, 185-200. https://doi.org/10.11646/phytotaxa.376.5.1

[2] Khassanov, F.O. and Rakhimova, N. (2012) Taxonomic Revision of the Genus Iris L. (Iridaceae Juss.) for the Flora of Central Asia. Stapfia, 97, 174-179.

[3] Tojibaev, K.Sh., Karimov, F.I., et al. (2014) A New Species of the Genus Iris L. (Iridaceae Juss.) from the Fergana Valley. Turczaninowia, 17, 12-16. https://doi.org/10.14258/turczaninowia.17.4.2

[4] Khassanov, F.O., Khuzhanazarov, U., et al. (2013) Two New Species of Iris L. (Iridaceae Juss.) from Uzbekistan. Stapfia, 99, 1-3.

[5] Lazkov, G.A. and Naumenko, A.N. (2014) A New Species of the Genus Juno Tratt. (Iridaceae) from Kyrgyzstan. Turczaninowia, 17, 32-34.

https://doi.org/10.14258/turczaninowia.17.2.4

[6] Goldblatt, P., Henrich, J.E. and Rudall, P. (1984) Occurrence of Crystals in Iridaceae and Allied Families and Their Phylogenetic Significance. Annals of the Missouri Botanical Garden, 71, 1013-1020. https://doi.org/10.2307/2399238

[7] Wu, Q.G. and Cutler, D.F. (1985) Taxonomic, Evolutionary and Ecological Implications of the Leaf Anatomy of Rhizomatous Iris Species. Botanical Journal of the Linnean Society, 90, 253-303. https://doi.org/10.1111/j.1095-8339.1985.tb00385.x

[8] Rudall, P. (1986) Taxonomic Significance of Leaf Anatomy in Australasian Iridaceae. Nordic Journal of Botany, 6, 277-289. https://doi.org/10.1111/j.1756-1051.1986.tb00879.x

[9] Rudall, P. (1994) Anatomy and Systematics of Iridaceae. Botanical Journal of the Linnean Society, 114, 1-21. https://doi.org/10.1111/j.1095-8339.1994.tb01920.x

[10] Meidner, H. and Mansfield, T.A. (1968) Physiology of Stomata. McGraw-Hill, London, 4.

[11] Cutter, E.G. (1978) Cells and Tissues. In: Plant Anatomy, Part I, Edward Arnold, 
London, 106-143.

[12] Wilkinson, H.P. (1979) The Plant Surface (Mainly Leaf). Stomata. In: Metcalfe, C.R. and Chalk, L., Eds., Anatomy of the Dicotyledons, Clarendon Press, Oxford, Vol. 1, 97-117.

[13] Esau, K. (1977) Anatomy of Seed Plants. John Wiley \& Sons, New York, 88.

[14] Wilder, G.J. (1985) Anatomy of Noncostal Portions of Lamina in the Cyclanthaceae (Monocotyledoneae). Epidermis. Botanical Gazette, 146, 82-105. https://doi.org/10.1086/337503

[15] Bacic, T. (1982) Broj i velicina stoma u hrastova Quercus robur L., Quercus cerris L. i Quercus frainetto Ten. i njihove ovisnosti o ekoloskim faktorima. Zbomik radova za prirodne nauke Matice srpske, 62, 67-74.

[16] Nikolic, T. (1997) Phenotypic Epidermis Plasticity in Population of Ranunculus acris L. (Ranunculaceae) under Different Light Conditions. Natura Croatica, 6, 335-344.

[17] Pazourek, J. (1970) The Effect of Light Intensity on Stomatal Frequency in Leaves of Iris hollandica hort., var. Wedgwood. Biologia Plantarum, 12, 208-215. https://doi.org/10.1007/BF02920869

[18] Knecht, G.N. and O'leary, J.W. (1972) The Effect of Light Intensity on Stomate Number and Density of Phaseolus vulgaris L. Leaves. Botanical Gazette, 133, 132-134. https://doi.org/10.1086/336626

[19] Luchansky, T.W. and Clough, K.D. (1986) Comparative Anatomy and Morphology of Asclepias perennis and Asdepias tuberosa subsp. rolfsii. Botanical Gazette, 147, 290-301. https://doi.org/10.1086/337596

[20] Mitic, B., Nikolic, T. and Liber, Z. (2000) Morphological and Anatomical Relationships in Alpine-Dinaric Populations of the Genus Iris L. Pallidae Series (A. Kern.) Trinajstic (Iridaceae). Acta Societatis Botanicorum Poloniae, 69, 285-291. https://doi.org/10.5586/asbp.2000.038

[21] Mitic, B. and Pavletic, Z. (1995) Morphologic and Anatomical Analysis of the Leaves of Iris cengialti Ambrosi f. Vochinensis Paulin. Bioloski Vestnik, 40, 1-5.

[22] Kandemir, N., Çelik, A., Ullah, F., Shah, S.N. and Zaman, W. (2019) Foliar Epidermal Anatomical Characteristics of Taxa of Iris subg. Scorpiris Spach (Iridaceae) from Turkey. Microscopy Research and Technique, 82, 764-774. https://doi.org/10.1002/jemt.23221

[23] Rakhimova, N.K. and Duschanova, G.M. (2017) Morpho-Anatomical Structure of Vegetative Organs Iris svetlanae (Vved.) F.O. Khass. (Iridaceae Juss.) Growing in Uzbekistan. International Scientific Journal “Internauka”. Kiev, 2, 11-14. (In Russian)

[24] Rakhimova, N.K. and Duschanova, G.M. (2017) The Anatomical Structure of the Leaf of Some Endemic Species of the Genus Iris L. under Conditions of Introduction. International Scientific Journal “Internauka”. Kiev, 8, 12-16. (In Russian)

[25] Duschanova, G.M., Rakhimova, N.K. and Abdinazarov, S.H. (2017) Adaptive Signs of a Leaf of Some Endemic Species of the Genus Iris L. from Different Sections under Conditions of Introduction in Uzbekistan. Journal of Novel Applied Sciences. $U A E, 6,113-118$.

[26] Rakhimova, N.K., Duschanova, G.M. and Abdinazarov, S.H. (2017) Structural Features of Leaves of Some Endemic Species of the Genus of Iris L. from the Section Hexapogon (Bunge ex Alef.) Baker in Conditions of Introduction. Journal of Novel Applied Sciences, UAE, 6, 119-123. 
[27] Abdinazarov, S.H., Rakhimova, N.K. and Duschanova, G.M. (2017) The Study of the Anatomical Structure of the Vegetative Organs of the Endemic Species Iris alberti Regel in the Introduction of the Botanical Garden of Uzbekistan. Journal of Novel Applied Sciences, UAE, 6, 124-129.

[28] Rakhimova, N. (2019) Iris magnifica (Vved.) F. O. Khass. et Rakhimova. Red Book of the Republic of Uzbekistan. Chinor ENK, Tashkent, 1, 78-79. (In Russian)

[29] Mathew, B. (1981) The Iris. Batsford Ltd., London, 202.

[30] Vvedensky, A.I. (1941) Juno Tratt. Yunona. Flora Uzbekistana. Uzbek Branch of the Academy of Sciences of the USSR, Tashkent, Vol. 1, 512-520. (In Russian)

[31] Barykina, R.P., Veselova, T.D., Devyatov, A.G., Dzhalilova, Kh., Ilyina, G.M. and Chubatova, N.V. (2004) Handbook of Botanical Microtechnology (Foundations and Methods). Moscow State University Press, Moscow, 312. (In Russian)

[32] Esau, K. (1969) Plant Anatomy. Mir, Moscow, 554. (In Russian)

[33] Aneli, N.A. (1975) Atlas of the Epidermis of the Leaf. Metznireba, Tbilisi, 105. (In Russian)

[34] Zaitsev, G.N. (1991) Mathematics in Experimental Botany. Science, Moscow, 296. (In Russian) 